\title{
THE RESPONSIBILITY OF ALL CONSUMER LENDING AGENCIES TO HELP ELIMINATE THE LOAN SHARK EVIL
}

\author{
J. MILLER REDFIELD*
}

Whether or not it is a weakness of our governmental and economic systems may be debatable, but the fact remains that when the individuals' demands for goods and services cannot be met legally, they will be met illegally. As evidence of this statement, one needs only to think of our "noble experiment," prohibition, rationing during World War II, and rent control which is still in effect in some areas. In all of these attempts to prohibit or strictly control the supplying of consumers' demands, ways were devised to circumvent the restrictions imposed by law. Numerous other examples of a similar nature could be cited. The absence of legal means, in certain areas of this nation, to adequately meet the individuals' need for comparatively small cash loans is the subject with which we are concerned in this article. The inescapable conclusion appears to be that, since the needs and desires of individuals cannot be legislated out of existence, the only alternative is to provide for the means of supplying any legitimate demands in the manner most beneficial to society as a whole.

\section{Why Do LOAN SHarks Exist?}

The term "loan shark" has been widely, and at times rather loosely, used for centuries. Many people use it to denote any lender whose rate of charge they deem unreasonable. Some lending agencies have used it to designate other lenders whose rates are higher than their own. Probably the most proper use of the term is as a designation of unscrupulous, illegal lenders whose charges and practices are extremely oppressive to the necessitous borrower of small sums. The nearest approach to a definition of the term in Webster's Dictionary is, "shark; (3) a rapacious, crafty person who gains by usury, extortion, swindling, and the like; as, a mortgage shark."

The loan shark is the offspring of two parents, the borrower's ignorance and traditional legislative policy. The borrower's ignorance is characterized by his failure to understand the concealment of a usurious interest rate or the harsh provisions for enforcement of the loan contract-such as confession of judgment, waiver of notice, appointment of the lender as borrower's attorney in fact and the provision for renewals on default, which further raises the interest rate. The limitation of interest by usury statutes not only bars the development of a lawful small loan business but encourages rates beyond those commercially profitable in order to compensate for the stigma of illegality and the fear of loss of interest or principal according to statute. ${ }^{2}$

- Executive Secretary, California Loan and Finance Association.

2 Webster's New International Dictionary 2303 (2d ed., unabridged, 1950).

2 I4 ENCYc. Soc. ScI. 107 (1934). 
The existence of loan sharks since Biblical times is a matter of record. Their operations on a widespread, commercialized scale in this country reached the zenith during the past half century. The change of the economy of this nation from one which was predominantly agricultural to one primarily industrial brought with it the shift of population from farms and small communities to large cities.

It took families out of the intimate community groups and placed them in the impersonal setting of large cities. Emergencies no longer called forth the friendly aid of neighbors. Each family was on its own. Families hit by emergencies instinctively sought aid through credit. But the average family found to its dismay that it could obtain no credit, or could secure it only under intolerable conditions. ${ }^{3}$

Some borrowers were able to obtain credit from remedial loan societies which made loans to wage earners on a semi-charitable basis. These organizations were the real pioneers. They led the way in showing the public that consumer lending was needed and was here to stay. Their organizers recognized the need for higher interest rates than those allowed under the usury laws and obtained special state charters permitting them to make these higher charges. The first society was founded in Boston in 1859. Other societies followed slowly but never became sufficiently numerous to meet more than a small part of the demand. ${ }^{4}$

The demand for cash loans of comparatively small amounts by average or below average income families has increased side by side with the further industrialization of our economy. Consumer loans will always be in demand by these families to meet emergencies and pressing obligations. As has been previously stated in this article, and on many other occasions, the demands of the public for goods and services will be met illegally if they cannot be met legally.

Legislative enactment cannot change economic law. If money is a commodity, the rate of interest is regulated, at least in part, by the law of demand and supply. Just as the medieval prohibitive usury laws could not be enforced, so do the modern restrictive usury laws meet administrative difficulties. The difficulties are greatest in the field of consumers' loans, loans for consumptive purposes. The borrowers are often ignorant and always in immediate need. They are therefore likely to be willing to accept whatever terms the lenders may ask. ${ }^{5}$

A natural assumption might be that with the substantial increase in hourly wage rates and gross income of wage earners which has occurred during the past twenty years, the need for small consumer loans would be substantially reduced. Undoubtedly this higher income, together with the increased cost of living, has been the major cause of the increase in the average size of loan made by legal consumer loan companies. Unfortunately, there is still a very sizable portion of our population which has great difficulty in making their income do more than meet bare living expenses.

\footnotetext{
${ }^{3}$ Wallace P. Mors, Consumer Credit Facts for You 4 (Bureau of Business Res., Western ReSERVE UNIVERSITY, I952).

Id. at $4-6$.

¿D. J. Galiert, W. S. Hilborn and Geoffrey May, Small loan Iegistation it (Russelt Sage Foundation, 1932).
} 
According to the Federal Reserve Bulletin for June, I953, II per cent of the spending units in the nation had incomes of less than $\$ 1,000$ and another $I_{4}$ per cent had incomes of between $\$ 1,000$ and $\$ 2,000{ }^{6}$ Families in these income groups are those most likely to encounter desperate need for emergency loan service. They seldom have sufficient reserves to tide them over emergency situations.

Liquid asset holdings (United States Government bonds, checking accounts, savings accounts in banks, postal savings, and shares in savings and loan associations and credit unions) are the usual reserves to meet emergencies. Yet 60 per cent of the spending units with incomes of less than $\$ 1,000$ had no such holdings of any nature, and 49 per cent of those with incomes from $\$ 1,000$ to $\$ 2,000$ were in the same situation. ${ }^{7}$ Furthermore, 44 per cent of those in the first income group felt they are "worse off" in 1953 than they were in 1952, and 34 per cent of those in the second group were of the same opinion. ${ }^{8}$

With 25 per cent of our families having incomes of less than $\$ 2,000$ and with the majority of those families having no liquid assets as reserves, the need for emergency loan service is very real. Such loan service cannot be provided within the limits set by general usury laws. Loan sharks will continue to exist wherever laws fail to provide for legal means of meeting borrowers' needs and demands for adequate consumer loan service.

\section{How Can Loan Sharks Be Eliminated?}

The question of how to eradicate loan shark operations, and the resultant oppression of necessitous borrowers, has received much attention during the past half century. Social agencies, legal aid societies, better business bureaus, prosecuting officials, and civic leaders have given much attention to this problem. While action by these groups has afforded some relief in individual cases which have been brought to their attention, such action alone has not solved the basic problem. "The illegal lender is endowed with a shrewd business sense. He will be deterred from continuing his enterprise only when its continued operation ceases to yield a profit or when the owner of the business is placed in personal jeopardy." Even severe penalties in the usury law fail to deter the loan shark. As a general rule, the greater the risk resulting from more severe penalties, the higher the charges to the unfortunate borrower.

History has conclusively proved that the only effective means of eliminating the loan shark has been the enactment of legislation patterned after the Russell Sage Foundation Uniform Small Loan Law. The two basic principles of this law were, (I) to attract legitimate capital into the small loan business by legalizing rates which would produce a reasonable profit and, (2) to prevent abuse of those using

\footnotetext{
${ }^{2}$ I953 Survey of Consumer Finance, Table 1, p. 2 (reprinted from Federal Reserve Bulletin, Junc, 1953).

Id. Table 8 , p. 4 .

Id. Table 12, p. I4.

' From an address by Charles Scott Kelly of the Chicago Bar at the September, r939, convention of the American Association of Personal Finance Companies.
} 
this service by imposing severe penalties for violations of the laws and providing for supervision by state authorities over those engaged in the business. The penalties for violations apply not only to those licensed under the law but also to those who engage in the business without obtaining a license. Neither adequate rates nor severe penalties alone can wipe out loan shark operations. It requires the combination of legal commercially profitable rates and comprehensive prohibitions and penalties to accomplish this task.

There have been some instances where drastic rate reductions in the small loan law have made it necessary for legal loan companies to discontinue their service. In every such instance the old-time loan sharks, and some new ones, appeared on the scene with their illegal charges and oppressive tactics, in spite of the fact that the penalty provisions of the law were still in the statutes. However, laws which provide for adequate rates but have loopholes, such as failure to prohibit salary buying, have also failed to eradicate loan sharks. The most recent example of what happens when a small loan law is rendered ineffective occurred in the state of Missouri.

After having had a small loan law for some time, the state suddenly found itself without one on July r, 1946 . This resultrd from a decision of the Missouri Supreme Court that the state's new constitution had repealed the small loan law. The clause which led to this decision requires that statutes fixing maximum interest rates shall apply to all lenders without regard to their type of business.

Nullification of the small loan law resulted in an extremely confused situation which impaired the entire credit structure of the state. Consumer finance companies liquidated and left. Commercial banks were unable to fill the breach. In fact, bank loans to consumers grew less rapidly in Missouri than in the country as a whole between 1946 and 195I. Illegal lenders stepped into the credit vacuum. "Almost immediately after July $I$, 1946, the old loan sharks, with out-of-state headquarters, began returning to Missouri . . . they brought with them both old and new schemes and methods of collecting exorbitant interest and charges." This is the conclusion of a study called "Illegal Lending in Missouri" which appeared in the June, I95I, issue of the Missouri Law Review. ${ }^{10}$

The unwillingness of loan shark victims to aid in the prosecution of illegal lenders is one of the handicaps encountered in eliminating loan sharks. So, too, are the ineffective penalties in the usury laws. This was proved in the recent experience in Missouri.

Out of hundreds of complaints claiming usury, only a few people were willing to subject themselves to publicity resulting from criminal prosecution. Of the few convictions obtained in Jackson County, the highest fine was $\$ r o o$, and this case is pending on an appeal to the Supreme Court by the usurer. In spite of convictions and fines, all of the loan sharks prosecuted have continued to operate as before. Contrary to general belief, most of the families victimized by loan sharks are middle class people who try to avoid publicity resulting from being implicated in a criminal prosecution.

Mr. Henry H. Fox, Jr., Prosecuting Attorney of Jackson County, Missouri, who has made many sincere efforts to prosecute loan sharks during his two terms of office, says,

${ }^{10}$ Birkhead, Murray, and Lochmoeller, Illegal Lending in Missouri, I6 Mo. L. REv. 25I, 253 (195I); Small Loan Laws of the United States 20 (Western Reserve University, Bureau of Business Res., 9th ed., 1952). 
"There can be no successful prosecution or elimination of loan shark practices without an effective small loan law."11

Missouri once again rid the state of loan sharks by enacting a new consumer credit loan act in $x 95$ I.

One reason for the success of the small loan law in driving out the loan sharks has been the policing work done by those operating under the law. The licensed companies are always on the alert for any evidence of illegal lending in the consumer loan field and do not hesitate to initiate action to stop the illegal lender. The national and state associations of licensed consumer loan companies have adopted codes of ethics and standards of business conduct which carry out the spirit as well as the letter of the law and which, with few exceptions, are observed by the industry.

The best proof that effective consumer loan laws do eliminate the loan shark is the fact there are no known loan sharks operating in those states having such a law. There may possibly be a few "hip-pocket" lenders but even they are very rare and the large scale loan shark operators are conspicuous by their absence. This statement is borne out by the action of the San Francisco Remedial Loan Association, one of the societies previously mentioned in this article, in dissolving the Association and withdrawing from the loan field. A news story on this action in the August I4, r95I issue of the San Francisco Examiner stated, "The 'loan shark' evil which the institution was organized to combat has been abated effectively by legislation, President M. H. Robbins observed. ... It has never been the purpose of the association to enter the competition of the loan business, Robbins said. It was organized to correct an existing situation-the charging of high rates of interest to needy and small borrowers."

\section{Where Do Loan Sharks Exist?}

Accepting the premise that loan sharks can be eliminated only by enactment of laws patterned after the Uniform Small Loan Law, it follows that loan sharks exist in those states which do not have such laws. That fact is widely known but the full extent of loan shark operations is not readily apparent, even to many of the citizens of those states. In some of the states with no effective law, a few lenders attempt to meet the demand for loans at rates which are fair though of questionable legality. They are the exception, however, and most lenders follow the well known loan shark pattern. ${ }^{12}$

Eight states and the District of Columbia now have largely or wholly inoperative consumer loan laws and four other states have no law of this nature. The states with inoperative laws are Alabama, Arkansas, Delaware, Georgia, Mississippi, North Carolina, Tennessee, and Texas. The states with no consumer loan laws are Kansas, Montana, North Dakota, and South Carolina. ${ }^{13}$ Over 20 per cent of the total

\footnotetext{
11 Bulletin of Better Business Bureau of Kansas City, Mo., Dec. 13, 1950.

${ }^{12}$ Mors, op. cit. supra note 3 , at 24 .

${ }^{18}$ SMail Loan Laws of THE UNited States, op. cit. supra note 10, at 11 . The table on this page shows Wyoming as one of the states having an inoperative law and South Dakota as having no small loan law. During the 1953 legislative sessions, the Wyoming law was amended by increasing the
} 
population of the United States live in these states. ${ }^{14}$ The majority of these states lie in the south-east portion of the United States. Growing industrialization of this area, with its concentration of wage earners in urban areas, has been a comparatively recent development. This condition has greatly intensified the need for legal consumer loan service in these states.

It has been previously stated that families with incomes of less than $\$ 2,000$ are those most likely to have need for emergency loan service. In the "I952 Survey of Consumer Finances" issued by the Federal Reserve System, the percentage of spending units in various income brackets is shown, among other ways, according to four regions; North East, North Central, South, and West. The South Region includes East South Central, West South Central, and South Atlantic States other than Delaware. In the South Region, 42 per cent of the spending units had incomes of less than $\$ 2,000$ as contrasted with 2 I per cent in the North East, 24 per cent in the North Central, and 2I per cent in the West. ${ }^{15}$ These figures illustrate the pressing need for adequate legal emergency loan service in those states where the loan sharks are now concentrated.

\section{Why Have Some Efrorts to Pass Small Loan Laws Failed?}

Efforts to pass effective small loan laws in those states which do not have them have been made with varying degrees of intensity and success for many years. The failure of some of these efforts has been due generally to a combination of several circumstances.

Some states have the maximum rate of interest set by constitutional provision. This is a major stumbling block in the path of enactment of a Uniform Small Loan Law but it is not insurmountable. California had such a constitutional provision for many years and, in fact, still has it. In I934 a constitutional amendment was passed which reduced the usury rate from 12 per cent to ro per cent per annum but exempted from that limitation practically all established lending agencies including banks, savings and loan associations, industrial loan companies, credit unions, and personal property brokers. The authority to fix maximum rates for these "exempted lenders" was delegated to the state legislature. The legislature has subsequently fixed maximum rates for many, but not all, of these lenders. An interesting commentary on this situation is that while California does have a Small Loan Law, it is practically unused and consumer loan companies operate under the Personal Property Brokers Law. This is because "small loan companies" were not included among the "exempted lenders" in the constitutional amendment and consequently the rate section of the Small Loan Law provides for maximum interest of Io per cent per annum plus certain other charges. These other charges must be for actual outlays

loan limit from $\$ \mathrm{I} 50$ to $\$ \mathrm{I}, 000$, and South Dakota passed a new law entitled "Installment Repayment Small Loan and Consumer Finance Act."

I‘ SMali Loan Laws of the United States, op. cit. supra note zo, estimate based on Table 5 , at page 27.

19 1952 Survey of Consumer Finances, Pr. III, Supp. Table 6, p. 2 I (reprinted from Federal Reserve Bulletin, September, 1952). 
in connection with the loan but the total permissible charge on any loan is limited to the aggregate charge permissible under the Personal Property Brokers Law. This cumbersome rate section makes the California Small Loan Law almost entirely inoperative but effective regulation and consumer loan service is provided under the Personal Property Brokers Law.

Following several years of thorough study and the drafting of its first Uniform Small Loan Law in 19I6, the Russell Sage Foundation took an active part in recommending enactment of this legislation. The Foundation discontinued this particular activity in the thirties after passage of the law in the majority of populous states. While social and welfare agencies, bar associations, and numerous other groups in practically all states have endorsed the Uniform Small Loan Law and recommended its passage, the burden of actively sponsoring this legislation in recent years has largely fallen upon the companies and individuals operating under this type of law in those states which have it. These companies have naturally concentrated their efforts in those states which are more heavily industrialized and where the potential for consumer loan service is greatest. The active sponsorship of this legislation by these companies, however, seldom fails to bring forth the loan shark inspired charge of "carpet baggers" who are interested only in taking "tremendous profits" out of the state.

Differences of opinion on certain points may have lessened the united, active sponsorship of the law by lawful consumer loan companies in recent years. One such point is the type of rate statement and computation to be included in any new law. Some companies advocate retention of the all-inclusive charge computed at a per-cent-per-month rate on unpaid principal balances. Others advocate a dollar add-on or a discount-plus-fee basis. Both groups present valid arguments in support of their positions. Possibly the new Missouri law will serve as a prototype for new consumer loan laws. That law permits the charge to be made either on the basis of so many dollars-per-hundred-per-year on the original principal amount of the loan or at the equivalent monthly rate computed on unpaid principal balances. The question of whether life and health and accident insurance should be permitted in connection with consumer loans under this law is also highly controversial. It appears reasonable to believe that if these differences of opinion can be resolved, the passage of effective laws in those states where the loan sharks now hold forth may be hastened.

There have been occasions when a neutral or even openly hostile attitude on the part of other lending agencies has hindered passage of the small loan law. If such an attitude stems from "competitive thinking," it is shortsighted at best. Disregarding for the moment the social aspects of the loan shark evil, there is a definite economic need for the service provided by consumer loan companies. Furthermore, experience has proved this service supplements rather than detracts from the service offered by other legitimate lending agencies in the consumer loan field.

The primary reason for failure to pass a small loan law in those states which do 
not have one is the intense opposition by loan sharks. These operators naturally do not want to see the end of their highly profitable business and will resort to any means to achieve their goal. One of the favorite tricks of loan sharks is to get some well-meaning but misinformed person, preferably a legislator, to denounce the "exorbitant" rates authorized under the proposed law, not realizing that those rates are very low in comparison with the charges collected by the loan sharks. Another trick is to offer a legislator a bribe for his vote in favor of the bill. If the legislator does not recognize this stratagem, he naturally denounces the sponsors of the bill for attempting unlawfully to influence legislation. There are many ways of defeating legislation and the loan sharks are thoroughly familiar with them all-both lawful and unlawful.

With the loan sharks' area of operations being gradually diminished, we can expect their efforts to block further enactment of consumer loan laws to be intensified. In most of the "loan shark" states there are a few lenders who sincerely desire the passage of an effective law but they have been unable to instill this desire in enough of the other lenders in the state. The elimination of the loan sharks in the twelve states where they now operate will require the persistent, united efforts of all groups and individuals who believe in fair treatment for the necessitous borrower.

Why Is Elimination of the Loan Shark Evil the Responsibility of All Consumer Lending Agencies?

Much has been said and written about the rights of American citizens, particularly the right of an individual to do as he chooses so long as he does not transgress on the rights of others. There are many individuals who firmly believe in the principles of absolute freedom of contract and of caveat emptor. The large majority of our citizens, however, recognize the obligation of society to circumscribe the activities of those who through trickery, deceit, and position, would take advantage of the general public or any particular segment of it.

Arguments with some seeming degree of validity have been made against any regulation of the small loan business. It has been contended that the small loan business is based upon a natural demand and is not a creature of government, therefore, it should be left to itself-that borrowers of small sums and the lenders who supply their needs are deprived by regulation of their freedom to make such contracts as can be mutually agreed upon. Such arguments appear to be based upon the questionable theory that since our nation was founded upon and has prospered under the principle of "free enterprise," any form of regulation is opposed to freedom of business enterprise and therefore violates that principle. When courts considered the constitutionality of various small loan laws some years ago, they found that the wide difference in the bargaining positions of the lender and the borrower prevented real freedom of contract and that there was real danger of unconscionable oppressive tactics by the unregulated lender, and they therefore held the police power of the state made constitutional the regulation of lenders for the protection of necessitous borrowers. ${ }^{18}$

${ }^{10}$ Bogert, The Future of Small Loan Legislation, I2 U. of CHI. L. Rev. I, I5 (1944). 
The record of illegal loan shark practice in the United States is a dreary account of many subterfuges by which the shark places the necessitous householder in his debt and takes from him a return that is extortionate, frequently many times the amount of the loan. As the victim must borrow and has no bargaining power-nothing to trade with -he finds himself completely at the mercy of the lender. ${ }^{17}$

It must become obvious to the public, as it is already well known to the social worker, that the borrower of small sums is well nigh helpless as a bargainer. His need is urgent. It cannot wait. He has no way of meeting it out of his own resources. He must have credit or he must seek charity. Except for the crisis in which he finds himself, he can get along. The obvious answer to his problem is credit. But he has no material assets with which to guarantee his repayment of a loan. He is helpless in the hands of the unscrupulous, unless society will stand at his shoulder and see justice done. ${ }^{18}$

The most effective work in aiding loan shark victims has been done by welfare agencies and legal aid societies. Intercession by representatives of these groups will occasionally cause the loan shark to make a reasonable settlement rather than face legal action. Even though successful, this action usually provides only temporary relief and the need for a more permanent remedy is readily apparent. Their experience in attempting to help unfortunate borrowers has caused welfare and legal aid societies to be among the strongest supporters of adequate small loan legislation. ${ }^{10}$

The social aspect of protecting the necessitous borrower and relieving him from the oppression of loan sharks is the primary motivating influence in the movement to eliminate the loan shark evil. There are, however, definite economic reasons why this movement should be carried on to a successful conclusion.

The Report of the Receiver in a Kansas City, Kansas case shows that, of the rates charged by one illegal lender on more than 2,000 loans in Topeka, the lowest was 192 per cent a year and the highest was $4{ }^{18}$ per cent. High as these rates are, they take no account of additional charges imposed in connection with forced renewals. The rates are typical of those exacted by illegal lenders in all parts of the State. . . Kansas borrowers pay loan sharks an estimated minimum of $\$ 7,200,000$ a year. This is interest at the rate of 240 per cent on borrowings of $\$ 3,000,000$. If Kansas lenders charged the highest rate permitted in any regulated state, the charges would be only $\$ 1,260,000$, leaving Kansas citizens a balance of $\$ 5,940,000$ for use in legitimate business. . . .

The elimination of the excessive charges exacted by loan sharks in Kansas would, therefore, not only vastly improve the lot of individual borrowers but would permit an estimated $\$ 6,000,000$ a year to go into legitimate trade channels instead of the loan sharks' pockets. This same situation, with varying amounts depending largely on population, exists in the other "loan shark" states. For this reason, every business and professional man has a justifiably selfish motive in helping to rid his own state of loan sharks.

\footnotetext{
${ }^{17}$ Robert W. Kelso, Social Background of the Small Loan Business in the United States 23 (1948).

${ }^{18}$ Id. at $2 \mathrm{I}-22$.

${ }^{10}$ Mors, op. cit. supra note 3 , at 25.

${ }^{20} \mathrm{Id}$. at 12 .
} 
There is another economic reason which many may have overlooked. Consumer credit is a major factor in our business economy and our high standard of living which is the envy of the world. The consumer loan business conducted by lenders specializing in that field is an integral part of consumer credit. There are unquestionably thousands of families in the "loan shark" states who cannot qualify for loans from existing legitimate lenders but whose need for loans is not quite desperate enough to force them to go to loan sharks. These families, together with countless others who have occasional need for installment loans, could and would make intelligent use of the service available from legal consumer loan companies. Surveys have shown that the major part of loans made by these companies is used to refinance existing debts. This service therefore benefits not only the individuals who use it but creditors generally.

The lack of active support by other consumer lenders, particularly banks and credit unions, in the enactment of small loan laws doubtless stems to a considerable degree from a competitive attitude. However natural this thinking may be, it is, to a great extent, fallacious. There is a certain degree of "overlap," to be sure, in the services offered by all consumer lending agencies.: There can be no doubt, however, that it would be impossible for any one type of agency adequately to serve the entire consumer loan field.

In its battle against loan sharks, the Russell Sage Foundation sponsored and supported both small loan laws and credit union laws. It was apparent that, because of their co-operative nature and certain other advantages, credit unions could provide consumer loan service at a cost lower than that necessarily charged by commercial companies. It was recognized, however, that because of their limitations, credit unions could meet only a portion of the demands for small loans-that legitimate commercial capital must also serve this field if the loan sharks were to be eliminated.

The degree of competition between consumer loan companies and the personal loan departments of commercial banks has been the subject of many discussions. Robert W. Kelso, Professor of Social Science, University of Michigan, touched on this question in his testimony before The Committee for Enactment of Fair Lending Legislation in Missouri at a hearing in St. Louis on September 22, 1948. Professor Kelso stated he had estimated the overlapping between these two groups would be from 5 to not over ro per cent. He further stated that the accuracy of this estimate was borne out by a Kalamazoo, Michigan banker who made a survey of the accounts of certain loan companies in his own city and concluded the overlap was not over 8 per cent. Clyde William Phelps, Head of the Department of Economics, University of Southern California, made an interesting observation on this question in an article in the January, 1947, issue of the Banking Law Journal. He stated,

My interviews with executives in charge of personal loan departments of commercial banks revealed that a considerable number of applicants have to be turned down because 
the loan desired is too small or represents too great a risk and that frequently the would-be borrowers are directed by the bank to one of the small loan companies. In short, the tendency of the most progressive executives of bank personal loan departments is to regard the small loan companies generally as supplementing bank consumer installment lending service more than competing with it.

There can be no question but that the complete eradication of loan sharks is a goal greatly to be desired. Their oppression of necessitous borrowers is a blot upon our boasted freedom of opportunity for all citizens. With no national organization leading the fight against the scourge of loan sharks, the responsibility for taking such action rests squarely upon the shoulders of the social and welfare agencies, civic groups, bar associations, and business leaders in those states where the loan sharks still flourish. Legitimate consumer lending agencies now operating in those states can and do wield great influence on public opinion. Their active support of adequate, effective consumer loan legislation could mean the difference between its enactment and defeat. The elimination of the loan shark evil can be accomplished only by the wholehearted co-operation of all groups who can aid in achieving this goal. 